\title{
PENGARUH GAYA KEPEMIMPINAN, MOTIVASI, DAN DISIPLIN KERJA TERHADAP KINERJA KARYAWANPADA PT SARANA AGRO NUSANTARA MEDAN
}

\author{
Oleh: \\ Holfian DaulatTambun Saribu ${ }^{1)}$, \\ Sarah RifkaMMalau ${ }^{2)}$, \\ MirandaMalau ${ }^{3)}$ \\ Rumaya Sihotangn 4 , \\ LusiChristiani Tambunan ${ }^{5}$, \\ dan Irfan Inayah $\left.{ }^{6}\right)$ \\ Universitas PrimaIndonesia, Medan 12,34,5,6) \\ E-mail : \\ Holfiandts@yahoo.co.id 1) \\ Sarahmalau@ymail.com 2) \\ Mirandamalau1998@gmail.com 3 ) \\ rumavasihotang(gmail.com $\left.{ }^{4}\right)$ \\ lusylusytambunan@gmail.com 5) \\ nayah.irfan@yahoo.com ${ }^{6)}$
}

\begin{abstract}
The purpose of this study was to study the influence of Leadership Style, motivation, and Work Discipline on Employee performance at PT. Agro Nusantara facilities in Medan. The research method uses quantitative descriptive analysis. With a total of 163 people in this study, as many as 163 people. Data analysis techniques using the F Test, T Test, and Multiple Linear Regression. Based on the results of data analysis in this study shows that the leadership style (X1) has a positive influence on the performance of employees of PT SAN Medan. The results showed motivation (X2) had a significant positive effect on employee performance at PT SAN. The results showed work discipline (X3) work discipline did not have a positive or significant effect on employee performance at PT Sarana Agro Nusantara Medan.
\end{abstract}

Keywords: Leadership Style, Motivation, Work Discipline, and Performance

\section{ABSTRAK}

Tujuan dilakukannya penelitian ini ialah untuk mengetahui adanya pengaruh Gaya Kepemimpinan, motivasi, dan Disiplin Kerja terhadap kinerja Karyawan pada PT Sarana Agro Nusantara Medan baik sebagian maupun simultan. Metode penelitian menggunakan analisis deskriftif kuantitatif. Adapun populasi dalam penelitian ini ialah seluruh karyawan yang berjumlah sebanyak 163 orang. Teknik analisis data menggunakan Uji F, Uji T, dan Regresi Linier Berganda. Berdasarkan hasil analisis data dalam penelitian ini menunjukan bahwa secara parsial dapat dilihat bahwa gaya kepemimpinan $\left(\mathrm{X}_{1}\right)$ memiliki pengaruh secara positif maupun 
signifikan terhadap kinerja karyawan PT SAN Medan. Hasil penelitian menunjukan motivasi $\left(\mathrm{X}_{2}\right)$ memiliki pengaruh secara positif maupun signifikan terhadap kinerja kerja karyawan pada PT SAN. Hasil penelitian menunjukan disiplin kerja $\left(\mathrm{X}_{3}\right)$ disiplin kerja tidak memiliki pengaruh secara positif maupun signifikan terhadap kinerja kerja karyawan pada PT Sarana Agro Nusantara Medan.

Kata Kunci: Gaya Kepemimpinan, Motivasi, Disiplin Kerja, dan Kinerja

\section{PENDAHULUAN}

PT Sarana Agro Nusantara Medan (PT SAN) merupakan perusahaan yang bergerak dalam bidang jasa penyedia tanki timbun minyak sawit CPO (Crude Palm Oil) yang berkantor pusat di Jl. Imam Bonjol No.24 A-B Medan dan memiliki dua unit kantor yang yang terletak di Jl. Ujung Baru, Medan Belawan, dan Jl. Datuk Laksamana yang terletak di Riau. Kedua lokasi kantor unit tersebut memiliki sarana kantor, tangki timbun, gudang timbangan, bengkel, katel uap, ruang instalasi, pompa, pembangkit tenaga listrik, saluran pemipaan dan lainlain.

Dalam rangka persaingan global yang

semakin ketat, PT Sarana Agro Nusantara Medan memiliki misi untuk menjadi jasa penimbunan terbaik dengan teknologi yang tepat dan memenuhi standar internasional yang dapat bertahan secara konsisten dan berkesinambungan, namun untuk memenuhi misi tersebut bukanlah sesuatu hal yang mudah untuk diwujudkan mengingat masih rendahnya kemampuan yang dimiliki oleh tiap karyawan.

Berdasarkan hasil observasi terdapat beberapa permasalahan pada PT Sarana Agro Nusantara Medan dimana tingkat kepuasan kerja karyawan rendah sehingga berimbas pada kualitas kinerja karyawan dalam mencapai tujuan yang sebelumnya telah perusahaan tetapkan. Dari data yang peneliti dapatkan menunjukan bahwa periode januari 2019 hingga desember 2019 perusahaan gagal dalam mencapai target produksi. dimana pencapaian target hanya terjadi pada bulan Juli sebesar $120.17 \%$ dan Agustus $118.12 \%$, sisahnya perusahaan tidak pernah mampu untuk mencapai target.

Kegagalan dalam mencapai target produksi ini diduga berasal dari sistem kepemimpinan yang diterapkan didalam perusahaan. Pemimpin didalam perusahaan haruslah pemimpin yang mampu mempengaruhi, memotivasi, dan memberikan kontibusi yang baik demi keberhasilan organisasi, namun kepemimpinan di PT Sarana Agro Nusantara Medan dikatakan masih tidak efesien, karena dalam pelaksanaannya pemimpin kurang memberikan ketegasan terhadap karyawan, adanya hubungan komunikasi yang tidak berlangsung baik antar pimpinan dengan para karyawan, hal ini membuat kegiatan operasi dilapangan tidak berjalan lancar karena salahnya pekerjaan yang dilakukan oleh karyawan tidak diberikan kritikan atau masukan oleh pimpinan yang dapat memperbaiki kinerja karyawan tersebut, selain itu 
minimnya kehadiran pimpinan dan minimnya rapat yang diadakan oleh pimpinan juga menjadi penyebab aktivitas dilapangan kurang terkoordinir dengan baik.

Selain masalah kepemimpinan, diduga motivasi juga menjadi penyebab mengapa perusahaan sulit memperoleh target yang diinginkan. Kurangnya motivasi yang dimilki oleh para karyawan menjadi penyebab mengapa kualitas kinerja memburuk. Kurangnya evaluasi kinerja yang dilakukan pimpinan menghambat adanya penilaian apakah kinerja karyawan tersebut baik atau tidaknya hingga berimbas pada ketidakpuasan tersendiri bagi karyawan karena merasa apapun yang dilakukannya tidak akan mendapat apresiasi ataupun penghargaan. Kurangnya motivasi yang diberikan inilah yang menjadikan mengapa kinerja yang diberikan karyawan tidak maksimal.

Selain kepemimpinan dan motivasi, masalah selanjutnya ialah diduga dari kedisiplinan kerja karyawan. Kurangnya peran pimpinan serta dalam pemberian motivasi menjadikan karyawan tidak memiliki prinsip untuk terikat pada peraturan perusahaan, tidak adanya hubungan baik yang mengikat antar pimpinan dengan bawahan menjadikan karyawan kurang memiliki tujuan didalam perusahaan tersebut, sehingga banyak karyawan yang sering mangkir dari pekerjaannya seperti sering datang terlambat serta tingginya tingkat absensi.

\section{TINJAUAN PUSTAKA}

\section{GAYA KEPEMIMPINAN}

Menurut Miftah Thoha (2013;49), Gaya Kepemimpinan ialah kebiasaan atau perilaku yang biasa digunakan oleh seseorang ketika ingin mempengaruhi orang lain. Pada dasarnya gaya kepemimpinan ini dipakai oleh para pimpinan yang ada didalam suatu organisasi mempengaruhi bawahannya yang pengaplikasiannya dalam bentuk tingkah laku, tindakan, ataupun keperibadian.

Adapula indikator gaya kepemimpinan ialah sebagai berikut :
1. Kecerdasan
2. Keyakinan Diri
3. Ketekunan
4. Integritas
5. Bersosialisasi

Menurut Fahmi $(2018 ; 141)$, seorang pemimpin memiliki pengaruh besar dalam mendorong karyawan untuk lebih terampil sehingga meningkatkan kinerja karyawan. Peningkatan kualitas kinerja bawahan memiliki pengaruh dalam menciptakan kualitas kerja yang sebelumnya diharapkan akan memberikan hasil yang maksimal.

Menurut dalam Amirullah (2015;4) mengemukakan bahwa Kepemimpinan merupakan proses pemimpin memengaruhi pengikut untuk mengipretasikan keadaan/ lingkungan organisasi, pemilihan tujuan organisasi, pengorganisasian kerja dan motivasi.

Dalam jurnal Astria Khairizah, dkk (2015) mengungkapkan bahwa dengan adanya kepemimpinan maka seorang pemimpin akan mampu mempengaruhi bawahan dengan cara 
memotivasi dan mengarahkannya pada tugas yang akan dikerjakan.

\section{MOTIVASI}

Menurut Robert dan Angelo (2014:332), Motivasi merupakan proses fisikologis yang membangkitkan dan mengarahkan perilaku pada pencapaian tujuan ataugoal-directec behavior.

Adapula indikator motivasi ialah sebagai berikut :

1. Kinerja

2. Penghargaan

3. Tantangan

4. Kesempatan.

Menurut

Armstrong (2014:338), Proses manajemen kinerja dapat memotivasi orang untuk memperbaiki kinerja mereka dan mengembangkan kapabilitas.

Menurut bangun (2012:131) Bila seseorang termotivasi, ia akan mencoba mengulangi perbuatan sebelumnya akan tetapi kemungkinan kecil tingkat upaya yang tinggi akan mengantar pada kinerja dan memberikan keuntugan.

Menurut

Mangkunegara (2017:94) Mengemukakan bahwa Motivasi kerja didefenisikan sebagai kondisi yang berpengaruh membangkitkan, mengarahkan dan memelihara perilaku karyawan yang memiliki hubungan pada lingkungan kerja.

\section{DISIPLIN KERJA}

Menurut Hasibuan (2016:193), Kedisiplinan adalah fungsi operatif dari manajemen sumber daya manusia yang tepenting karena semakin baik disiplin karyawan, semakin tinggi prestasi kerja yang dapat dicapainya.
Adapula indikator disiplin kerja ialah sebagai berikut :

1. Kemampuan

2. Tujuan pimpinan

3. Balas jasa

4. Keadilan

5. Sanksi hukuman

Menurut Siagian (2015:305) Dengan perkataan lain pendisiplinan pengawai adalah suatu bentuk pelatihan yang berusaha untuk membenahi, dan menata serta mengasah pengetahuan, dan mengontrol perilaku karyawan.

Menurut Sutrisno (2016:96), mengemukakan bahwa disiplin merupakan faktor utama yang mempengaruhi faktor utama yang mempengaruhi produktivitas.

Menurut Hasibuan $(2013 ; 193)$ mengemukakan Displin merupakan fungsi yang biasa dipergunakan oleh manajemen sumber daya manusia untuk kepentingan perusahaan, jika disiplin yang dimiliki oleh karyawan tinggi, maka akan semakin tinggi pula prestasi kerja yang dapat dicapai.

\section{KINERJA}

Menurut

Wibowo (2018:7),Kinerja adalah manajemen yang berhubungan dalam menciptakan komunikasi yang terjalin efektif, manajemen kinerja fokus pada hal yang diperlukan oleh organisasi maupun perusahaan demi keberhasilan pekerjaan.

Menurut Afandi(2018:83) Kine rja adalah hasil kerja yang diraih oleh seseorang atau kelompok orang dalam suatu perusahaan sesuai dengan tanggung jawab yang diberikan dalam upaya pencapaian 
tujuan organisasi secara baik dan tidak melanggar norma hukum dan tidak bertentangan dengan moral dan etika.

Adapula indikator disiplin kerja ialah sebagai berikut :

1. Tujuan

2. Standar

3. Umpan balik

4. Alat atau sasaran

5. Kompetensi

6. Motif

\section{Hipotesis}

Berdasarkan kerangka konseptual diatas, maka hipotesis penelitian ini ialah sebagai berikut :

1. Gaya Kepemimpinan berpengaruh secara parsial terhadap Kinerja Karyawan pada PT. Sarana Agro Nusantara Medan.

2. Motivasi berpengaruh secara parsial terhadap Kinerja Karyawan pada PT. Sarana Agro Nusantara Medan.

3. Disiplin Kerja berpengaruh secara parsial terhadap Kinerja Karyawan pada PT. Sarana Agro Nusantara Medan.

4. Gaya Kepemimpinan, Motivasi, dan Disiplin Kerja secara bersama-sama berpengaruh terhadap Kinerja Karyawan pada PT. Sarana Agro Nusantara Medan.

\section{METODE PELAKSANAAN Lokasi Penelitian.}

Penelitian ini dilakukan di PT Sarana Agro Nusantara Medan (PT SAN). di Jl. Imam Bonjol No.24 A-B Medan.

\section{Pendekatan Penelitian}

Pendekatan penelitian ini berdasarkan pendekatan kuantitatif. Menurut Sugiono (2017:17) pendekatan kuantitatif adalah penelitian yang berdasarkan pada filsafat positivisme, dan digunakan oleh peneliti untuk mengetahui populasi atau sampel tertentu.

\section{Populasi dan Sampel Populasi}

Menurut Sugiyono (2017:115), populasi adalah sekumpulan generalisasi yang diliputi oleh objek atau subjek yang memiliki kualitas dan kuantitas tertentu yang akan ditetapkan peneliti untuk dipelajari lalu menarik kesimpulannya. Populasi pada penelitian ini ialah seluruh karyawan di PT Sarana Agro Nusantara Medan. Dimana jumlah karyawan sebanyak 163 orang.

\section{Sampel}

Menurut Sugiyono (2017:116), sampel adalah bagian dari jumlah populasi yang diambil untuk menjadi objek penelitian dengan memiliki karakteristik tertentu. Teknik pengambilan sampel dalam penelitian ini dengan menggunakan rumus

Slovin,

$$
\text { Yaitu : } \quad n=\frac{N}{1+\left(N \times e^{2}\right)}
$$

$$
\begin{aligned}
& \text { Keterangan : } \mathrm{n}=\text { jumlah sampel } \\
& \mathrm{N}=\text { jumlah pupolasi } \\
& \mathrm{e}=\text { standar eror }
\end{aligned}
$$

Berdasarkan rumus slovin dapat diketahui jumlah sampel penelitian adalah 109. Dan memilih beberapa orang karyawan secara 
acak diobjek penelitian sebanyak 30 untuk uji validitas dan reliabilitas yang diambil dari populasi diluar sampel.

\section{Teknik Pengolahan Data}

\section{Uji Validitas}

Ghozali (2016:52),Uji validitas ini digunakan untuk mengukur apakah suatu kuesioner layak untuk dipakai. Suatu kuesioner dinyatakan valid apabila pernyataan yang ada didalam kuesioner mampu mengungkapkan atau menjawab sesuatu yang akan diukur.

Pengujian pada penelitian ini menggunakan signifikasi 5\% dengan kriteria pengujian bila nilai thitung $>$

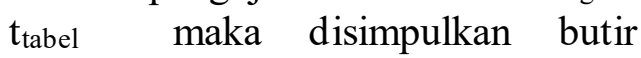
pertanyaan valid, sebaliknya bila thitung $<\mathrm{t}_{\text {tabel }}$ maka disimpulkan bahwa butir pertanyaan tidak valid.

\section{Uji Reliabilitas}

Ghozali

(2016:47-48),

Reliabilitas sebenarnya adalah alat untuk mengukur suatu kuesioner yang merupakan bagian indikator dari variabel atau konstruk. Suatu kuesioner dikatakan reliable apabila jawaban yang seseorang ungkapkan pada peryataan tetap stabil dari waktu ke waktu.

Pengukuran kemudian dibandingkan dengan pertanyaan lainnya menggunakan uji statistik Cronbach's Alpha. Dengan kriteria dikatakan reliabel apabila suatu variabel memiliki nilai Cronbach's Alpha $>0,70$.

\section{Metode Analisis Data \\ Uji Asumsi Klasik}

Uji asumsi klasik merupakan prasyarat utama untuk melakukan analisis regresi berganda. Adapun uji asumsi klasik (Ghozali: 2013) yang digunakan dalam penelitian ini adalah Uji Normalitas, Multikolinearitas, dan Heterokedastisitas.

\section{Analisis Regresi Linear Berganda}

Metode analisis regresi linear berfungsi untuk mengetahui pengaruh hubungan antara variabel independen dan variabel dependen. Rumus perhitungan persamaan regresi berganda adalah sebagai berikut

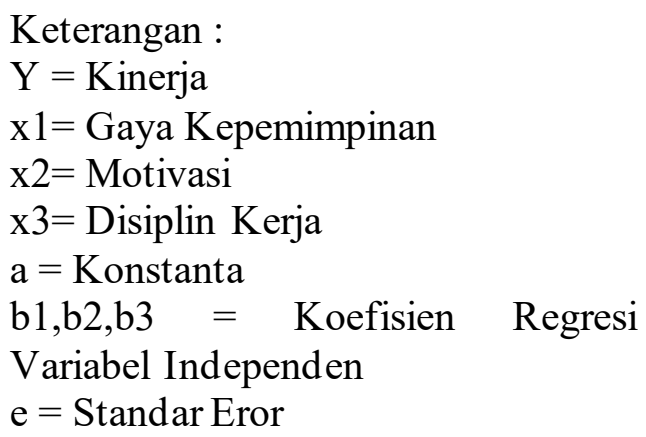

\section{Uji $\mathbf{R}^{\mathbf{2}}$ (Koefisien Determinasi)}

Ghozali (2016:97), menyatakan bahwa koefisien determinasi pada intinya digunakan untuk mengukur sejauh mana kemampuan model pada penelitian menjelaskan variable dependen. Nilai koefisien determinan adalah antara nol dan satu. Nilai Adjusted $\mathrm{R}^{2}$ bisa bernilai negative, walaupun yang dikehendaki bernilai positif.

\section{Uji Hipotesis \\ Uji Secara Simultan (Uji F)}

Uji signifikan dari regresi sampel (Uji Statistik F) tidak seperti uji $\mathrm{t}$ yang menguji signifikan 
koefisien parsial regresi secara individu dengan uji hipotesis terpisah bahwa setiap koefisien regresi sama dengan nol. Uji $F$ menguji joint hipotesis bahwa b1,b2. Dan b3 secara simultan sama dengan nol, atau :

$$
\begin{aligned}
& \text { a. } \mathrm{H} 0: \mathrm{b} 1=\mathrm{b} 2=\ldots \ldots \ldots \ldots=0 \\
& \text { b. HA : } \mathrm{b} 1 \neq \mathrm{b} 2=\ldots \ldots \ldots \ldots \neq 0 \\
& \text { Nilai } \quad \text { Fhitung } \quad \text { akan }
\end{aligned}
$$
dibandingkan dengan Ftabel. Kriteria pengambilan keputusannya adalah :

a. Ha diterima jika Fhitung $>$ Ftabel dan nilai sig $<0,05$

b. H0 ditolak jika Fhitung < Ftabel untuk nilai sig $>0,05$

\section{Uji Secara Parsial (Uji t)}

Ghozali (2016:97), uji statistik t pada dasarnya menunjukan seberapa jauh pengaruh satu variabel penjelas/independen secara individual dalam menerangkan variasi variabel dependen hipotesis nol (Ho) yang hendak diuji adalah apakah suatu parameter (bi) sama dengan nol, atau :

a. Ho : bi $=0$ (suatu variabel independent bukan merupakan penjelasan yang signifikan terhadap variabel dependen)

b. Ha : bi $\neq 0$ (variabel tersebut merupakan variabel penjelasan yang signifikan terhadap variabel dependent)

\section{HASIL DAN PEMBAHASAN}

Peneilitian ini dilakukan dengan penyebaran kuesioner di PT Agro Nusantara Medan dengan sebaran kuesioner sebagai berikut:

Penelitian ini menggunakan kuesioner dengan skala Likert, maka sebelum pengolahan, data hasil penelitian diolah dulu menjadi data interval dengan Method Of Successive Interval.

\section{Uji Reliabilitas}

Tabel Uji Reliabilitas

\begin{tabular}{|c|c|c|}
\hline Variabel & $\begin{array}{c}\text { Cronbach' } \\
\text { s Alpha }\end{array}$ & $\begin{array}{c}\text { N of } \\
\text { item } \\
\text { s }\end{array}$ \\
\hline $\begin{array}{c}\text { Gaya } \\
\text { Kepemimpina } \\
\mathrm{n}\end{array}$ & 0,892 & 10 \\
\hline Motivasi & 0,903 & 8 \\
\hline Disiplin Kerja & 0,882 & 10 \\
\hline Kinerja & 0,779 & 8 \\
\hline
\end{tabular}

Sumber: Hasil Penelitian (Olahan Spss)

Berdasarkan hasil uji reliabilitas penelitian ini, nilai Cronbach's Alpha pada Gaya Kepemimpinan sebesar 0,892, Motivasi sebesar 0,903, Disiplin Kerja sebesar 0,779, dan Kinerja sebesar 0,779 lebih besar dari 0,70 yang mengatakan penelitian ini reliabel.

\section{Uji Asumsi Klasik Uji Normalitas}


Tabel 1 Hasil Uji Normalitas Kolmogorov-Smirnov One-Sample Kolmogorov-Smirnov Test

\begin{tabular}{|ll|r|}
\hline & & Unstandardized Residual \\
\hline $\mathrm{N}$ & Mean & 109 \\
Normal Parameters & $0 \mathrm{E}-7$ \\
& Std. & Deviation \\
& Absolute & 2.38850085 \\
& Positive & .043 \\
Most Extreme Differences & Negative & .036 \\
& & -.043 \\
Kolmogorov-Smirnov Z & & .449 \\
Asymp. Sig. (2-tailed) & & .988 \\
\hline
\end{tabular}

a. Test distribution is Normal.

b. Calculated from data.

Sumber: Hasil Penelitian, (olahan SPSS)

Penelitian ini menggunakan Uji normalitas dengan statistik non paramatik Kolmogorov-Smirnov dimana bertujuan untuk mengetahui apakah data sudah terdistribusi secara normal atau tidak. Uji normalitas adalah uji yang digunakan untuk mengetahui apakah distribusi data mendekati distribusi normal. Berdasarkan hasil pada tabel di atas diperoleh untuk variabel kinerja karyawan kolmogorov-smirnov sebesar 0,449 dengan asymp sig 0,988. Oleh

Berikut adalah hasil pengujian Multikolinearitas yaitu :

Tabel 2 Hasil Uji Multikolieritas

\begin{tabular}{|c|c|c|c|}
\hline \multirow{2}{*}{\multicolumn{2}{|c|}{ Model }} & \multicolumn{2}{|c|}{ Collinearity Statistics } \\
\hline & & Tolerance & VIF \\
\hline \multirow{4}{*}{1} & (Constant) & & \\
\hline & Gaya Kepemimpinan & .953 & 1.044 \\
\hline & Motivasi & .986 & 1.015 \\
\hline & Disiplin Kerja & .967 & 1.035 \\
\hline
\end{tabular}

a. Dependent Variable: Kinerja

Sumber: Hasil Penelitian, (olahan SPSS)

Tabel diatas menunjukan bahwa nilai tolerance tiap variabel independen sebagai Gaya

Kepemimpinan $\left(\mathrm{X}_{1}\right)$ sebesar 0,953 , motivasi $\left(\mathrm{X}_{2}\right)$ sebesar 0,986 dan disiplin kerja $\left(\mathrm{X}_{3}\right)$ sebesar 0,967 
lebih besar dari 0,1 sedangkan nilai VIF tiap variabel independe Gaya Kepemimpinan $\left(\mathrm{X}_{1}\right)$ sebesar 1,044, motivasi $\left(\mathrm{X}_{2}\right)$ sebesar 1,015 dan disiplin kerja $\left(\mathrm{X}_{3}\right)$ sebesar 1,035 lebih kecil dari 10, maka data tersebut terbebas dari multikolinearitas.

\section{Uji Heterokedastisitas}

Tabel 3. Hasil Uji Heterokedastisitas

Coefficients $^{\mathbf{a}}$

\begin{tabular}{|rl|r|r|}
\hline Model & \multicolumn{1}{|c|}{$\mathrm{t}$} & \multicolumn{1}{c|}{ Sig. } \\
\hline \multirow{2}{*}{1} & (Constant) & 1.783 & .077 \\
& Gaya & .314 & .754 \\
& Kepemimpinan & -1.633 & .106 \\
& Motivasi & -.640 & .524 \\
\hline
\end{tabular}

a. Dependent Variable: RES2

Sumber: Hasil Penelitian, (olahan SPSS)

Tabel 3. diatas menunjukan nilai signifikan dari variabel bebas gaya kepemimpinan sebesar $0,754>0,05$, variabel bebas motivasi $0,106>0,05$, variabel bebas disiplin kerja sebesar
$0,524>0,05$. Dengan demikian dari hasil uji Gletjer dapat dikatakan tidak terjadi masalah heteroskedastisitas.

\section{Analisis Regresi Linear Berganda}

Tabel 4. Hasil Model Regresi Linear Sederhana Coefficients ${ }^{\mathbf{a}}$

\begin{tabular}{|c|c|c|c|c|c|c|}
\hline \multirow{2}{*}{\multicolumn{2}{|c|}{ Model }} & \multicolumn{2}{|c|}{$\begin{array}{c}\text { Unstandardized } \\
\text { Coefficients }\end{array}$} & \multirow{2}{*}{$\begin{array}{c}\text { Standardized } \\
\text { Coefficients } \\
\text { Beta } \\
\end{array}$} & \multirow[t]{2}{*}{$\mathrm{t}$} & \multirow[t]{2}{*}{ Sig. } \\
\hline & & B & Std. Error & & & \\
\hline \multirow{4}{*}{1} & (Constant) & 14.794 & 4.278 & & 3.458 & .001 \\
\hline & $\begin{array}{l}\text { Gaya } \\
\text { Kenemimninan }\end{array}$ & .201 & .072 & .256 & 2.788 & .006 \\
\hline & Motivasi & .266 & .076 & .317 & 3.499 & .001 \\
\hline & Disiplin Kerja & -.082 & .094 & -.080 & -.874 & .384 \\
\hline
\end{tabular}

a. Dependent Variable: Kinerja

Sumber: Hasil Penelitian, (olahan SPSS) 
Penjelasan regresi linier berganda diatas adalah :

1. Konstanta (a) sebesar 14.794 artinya apabila tidak terdapat nilai pada variabel gaya kepemimpinan, motivasi, dan disiplin kerja. Maka nilai kinerja karyawan diperusahaan itu adalah 14.794.

2. Variabel gaya kepemimpinan (X1) sebesar 0.201 yang berarti setiap kenaikan variabel gaya kepemimpinan sebesar 1 satuan. Maka nilai kinerja karyawan akan ikut naik sebesar 0.201 satuan dengan perkiraan variabel yang lain tidak berubah.

3. Motivasi (X2) sebesar 0.266 yang berarti setiap kenaikan variabel motivasi sebesar 1 satuan. Maka nilai kinerja karyawan akan naik 0.266 satuan dengan perkiraan variabel yang lain tidak berubah.

4. Variabel disiplin kerja (X3) sebesar -0.082 yang berarti setiap kenaikan variabel disiplin kerja sebesar 1 satuan. Maka nilai kinerja karyawan akan naik sebesar 0.082 satuan dengan perkiraan variabel yang lain tidak berubah.

\section{Koefisien Determinasi Hipotesis}

Adjusted $R$ Square dengan $\mathrm{R}^{2}$ merupakan nilai koefisien determinasi terkoreksi yang menyesuaikan $\mathrm{R}^{2}$ dengan cara membagi tiap sum of square dengan derajat bebas masing-masing.

Tabel. 5. Uji Koefesien Determinasi

Model Summary

\begin{tabular}{|l|r|r|r|r|}
\hline $\begin{array}{l}\text { Mode } \\
1\end{array}$ & R & R Square & $\begin{array}{c}\text { Adjusted R } \\
\text { Square }\end{array}$ & $\begin{array}{r}\text { Std. Error of } \\
\text { the Estimate }\end{array}$ \\
\hline 1 & $.387^{\mathrm{a}}$ & .150 & .126 & 2.422 \\
\hline
\end{tabular}

a. Predictors: (Constant), Disiplin Kerja, Motivasi, Gaya

Kepemimpinan

Sumber: Hasil Penelitian, 2020 (Data Diolah)

Berdasarkan tabel diatas bahwa dapat disimpulkan:

a) $\mathrm{R}=0.387$ berarti hubungan (corelation) antara variable Gaya kepemimpinan, motivasi, dan disiplin kerja terhadap variable kinerja tinggi.

b) Nilai Koefisien determinasi (R Square) adalah sebesar 0.150, hal ini menunjukan bahwa $15 \%$ variasi variable kinerja (Y) dapat dijelaskan oleh variable gaya kepemimpinan (X1), motivasi (X2) dan variable disiplin kerja (X3) sedangkan sisanya $85 \%$ adalah variable bebas lainnya yang tidak di jelaskan dalam penelitian ini. 


$\begin{aligned} & \text { Pengujian Hipotesis Secara } \\ & \text { Simultan (uji F) }\end{aligned}$
Tabel 6. Uji F
ANOVA

a. Dependent Variable: Kinerja

b. Predictors: (Constant), Disiplin Kerja, Motivasi, Gaya Kepemimpinan

Sumber: Hasil Penelitian, (olahan SPSS)

Berdasarkan Tabel diatas, demikian kepemimpinan $\left(\mathrm{X}_{1}\right)$, derajat bebas $1\left(\mathrm{df}_{1}\right)=\mathrm{k}-1=4-1=3, \quad$ motivasi $\left(\mathrm{X}_{2}\right)$, dan disiplin kerja $\left(\mathrm{X}_{3}\right)$ dan derajat bebas $2\left(\mathrm{df}_{2}\right)=\mathrm{n}-\mathrm{k}=109-\quad$ secara simultan (bersama-sama) 4=105, dimana $\mathrm{n}=$ jumlah sampel, $\mathrm{k}=$ berpengaruh secara positif maupun jumlah variabel, maka nilai $F_{\text {tabel }}$ signifikan terhadap variable kinerja pada taraf kepercayaan signifikansi (Y) pada PT Sarana Agro Nusantara 0,05 adalah 2,69. Hasil pengujian hipotesis diperoleh nilai $F_{\text {hitung }}$ sebesar 6.171 lebih besar dari $F_{\text {tabel }}$ sebesar 2.69 dengan sig. $0.001<0.05$ maka dari itu ini menunjukkan $\mathrm{H}_{0}$ Medan.

Pengujian Hipotesis Secara Parsial (Uji t)

Hasil uji t dapat dilihat pada Tabel berikut :

Tabel 7. Uji $\mathrm{t}$

Coefficients $^{\mathbf{a}}$

\begin{tabular}{|c|c|c|c|c|c|c|}
\hline \multirow{2}{*}{\multicolumn{2}{|c|}{ Model }} & \multicolumn{2}{|c|}{$\begin{array}{c}\text { Unstandardized } \\
\text { Coefficients }\end{array}$} & \multirow{2}{*}{\begin{tabular}{|c|}
$\begin{array}{c}\text { Standardized } \\
\text { Coefficients }\end{array}$ \\
Beta \\
\end{tabular}} & \multirow[t]{2}{*}{$\mathrm{t}$} & \multirow[t]{2}{*}{ Sig. } \\
\hline & & B & Std. Error & & & \\
\hline \multirow{4}{*}{1} & (Constant) & 14.794 & 4.278 & & 3.458 & .001 \\
\hline & $\begin{array}{l}\text { Gaya } \\
\text { Kepemimpinan }\end{array}$ & .201 & .072 & .256 & 2.788 & .006 \\
\hline & Motivasi & .266 & .076 & .317 & 3.499 & .001 \\
\hline & Disiplin Kerja & -.082 & .094 & -.080 & -.874 & .384 \\
\hline
\end{tabular}

a. Dependent Variable: Kinerja

Sumber: Hasil Penelitian, (olahan SPSS)

Berdasarkan Tabel diatas menunjukkan bahwa :

1. Variabel gaya kepemimpinan

$\left(X_{1}\right)$ memiliki thitung sebesar

2.788 dan nilai $t_{\text {tabel }}$ sebesar

1,658 maka nilai $t_{\text {thitung }}>t_{\text {tabel }}$

$(2.788>1,658)$ dan nilai

sig. $0.006<0,05$. Hal ini berarti 
hipotesis diterima yaitu : gaya kepemimpinan berpengaruh secara positif maupun signifikan terhadap kinerja kerja karyawan pada PT Sarana Agro Nusantara Medan.

2. Variabel motivasi $\left(\mathrm{X}_{2}\right)$ memiliki $t_{\text {hitung }}$ sebesar 3.499 dan nilai $t_{\text {tabel }}$ sebesar 1,658 maka nilai thitung $>$ tabel $\quad(3.499>1,658)$ dan nilai sig. $0.001<0,05$. Hal ini berarti hipotesis diterima yaitu : motivasi berpengaruh secara positif maupun signifikan terhadap kinerja kerja karyawan pada PT Sarana Agro Nusantara Medan.

3. Variabel disiplin kerja $\left(X_{3}\right)$ memiliki thitung sebesar -0.874 dan nilai $t_{\text {tabel }}$ sebesar 1,658 maka nilai $t_{\text {hitung }}<\mathrm{t}_{\text {tabel }} \quad(-$ $0.874>1,658)$ dan nilai sig. $0.384>0,05$. Hal ini berarti hipotesis ditolak yaitu : disiplin kerja tidak berpengaruh secara positif maupun signifikan terhadap kinerja kerja karyawan pada PT Sarana Agro Nusantara Medan.

\section{KESIMPULAN}

Berdasarkan hasil analisis dan pembahasan yang telah diuraikan paada bab sebelumnya, maka dapat ditarik kesimpulan sebagai berikut :

1. Pengujian hasil secara simultan menunjukan bahwa Gaya kepemimpinan, Motivasi, dan Disiplin kerja berpengaruh positif dan signifikan terhadap variable kinerja (Y) pada PT Sarana Agro Nusantara Medan.

2. Pengujian hasil secara parsial menunjukan bahwa Gaya kepemimpinan berpengaruh positif dan signifikan terhadap kinerja kerja karyawan pada PT Sarana Agro Nusantara Medan.

3. Pengujian hasil secara parsial menunjukan bahwa Motivasi berpengaruh positif dan signifikan terhadap kinerja kerja karyawan pada PT Sarana Agro Nusantara Medan.

4. Pengujian hasil secara parsial menunjukan bahwa Disiplin kerja tidak berpengaruh positif dan signifikan terhadap kinerja kerja karyawan pada PT Sarana Agro Nusantara Medan.

\section{DAFTAR PUSTAKA}

Afandi, P. (2018). Manajemen Sumber Daya Manusia (Teori, Konsep dan Indikator). Riau: Zanafa Publishing.

Amirullah. 2015. Pengantar Manajemen. Jakarta: Mitra Wacana Media.

Astria Khairizah, Irwan Noor, Agung Suprapto. 2015. Pengaruh Gaya Kepemimpinan,

Terhadap Kinerja Karyawan (Studi Pada Karyawan di Perpustakaan Universitas Brawijaya (Malang). Jurnal Administrasi Publik.

Bangun, Wilson. 2012. Manajemen Sumber Daya Manusia. Jakarta : Erlangga.

Edy Sutrisno. 2016. Manajemen Sumber Daya Manusia. Edisi Pertama. Jakarta: Kencana. Prenadamedia Group.

Fahmi, Irham 2018. Manajemen Sumber Daya Manusia. Teori 
dan Aplikasi. Bandung : Alfaberta CV

Ghozali, Imam.2013. Aplikasi Analisis Multivariate dengan Program IBM SPSS 21 Update PLS Regresi. Semarang: Badan Penerbit Universitas Diponegoro.

Kotler, Philip \& Amstrong. Gary. 2014.

Prinsip-prinsip Manajemen. Edisi 14. Jilid 1. Jakarta : Erlangga

Mangkunegara. 2017. Manajemen Sumber Daya Manusia. Perusahaan PT. Remaja Rosdakarya : Bandung

Miftah Thoha. 2013. Kepemimpinan Dalam Manajemen. Jakarta : Raja Grafindo Persada.

Robert Kreitner dan Angelo Kinicki. 2014.

Perilaku Organisasi. Jakarta : Salemba Empat.

Sondang P Siagian. 2015. Manajemen Sumber Daya Manusia. Jakarta : PT. Bumi Aksara

S,P, Hasibuan. Malayu. 2013. Manajemen Sumber Daya Manusia. Jakarta : PT. Bumi Aksara

Sugiono.2017. Metode Penelitian Bisnis (Pendekatan Kuantitatif, Kualitatif, dan $R \& D)$. Bandung: Alfabeta, Cv.

Wibowo. 2018. Manajemen Kinerja.

Edisi 5. Cetakan ke-10. Jakarta: PT Raja Grafindo Persada. 